\title{
Effect of Adriamycin on Lipid Peroxide, Glutathione Peroxidase and Respiratory Responses of Mitochondria from the Heart, Liver and Kidney
}

\author{
SUNG BOO YOON, KIMINORI KAJIYAMA, YUJI HINO, \\ MASAYASU SUGIYAMA AND RYOHEI OGURA \\ Department of Medical Biochemistry, Kurume University School of Medicine, \\ Kurume, 830 Japan
}

Received for publication April 4, 1983

\begin{abstract}
Summary: Administration of adriamycin induced an elevation of lipid peroxide content, a decrease of glutathione peroxidase activity and a disturbance of the respiratory responses in heart mitochondria. Cardiac mitochondria were much more sensitive to adriamycin, than mitochondria of the liver and kidney.
\end{abstract}

Key words: adriamycin - cardiotoxicity - mitochondria - lipid peroxide glutathione peroxidase - respiratory response

\section{Introduction}

Adriamycin (ADR), an important antitumor agent, is limited in clinical application due to a dose-dependent cardiotoxicity which can be lethal. The precise mechanism for this toxicity remains unknown. Myer et al. (1977) reported that ADR induced cardiac toxicity was associated with peroxi dation of cardiac lipids in mice. Both lipid peroxidation and cardiac toxicity of ADR were reduced by prior treatment with $\alpha$ tocopherol or other free radical scavenger. In our laboratory (Ogura et al. 1979, 1982), a short-term animal experiment demonstrated that the administration of ADR induced an elevation of lipid peroxidation, a decrease of CoQ-10 and an uncoupling of phosphorylation of cardiac mitochondria. These changes were accompanied by morphological changes in the mitochondria. To investigate the pathogenesis of the ADRinduced cardioselective toxicity, the membranous disorders of mitochondria prepared from the heart were compared with those of the liver and kidney.

\section{Materials and Methods}

Male Wister rats weighing about $200 \mathrm{~g}$ were injected, i. p., with $4 \mathrm{mg} / \mathrm{kg}$ of ADR (adriacin, Kyowa Hakko Kogyo Co. Ltd.) for 6 consecutive days. On the 7 th day, the animals were sacrificed by decapitation. The heart, liver and kidney were removed quickly and placed in an ice-cold solution of $10 \mathrm{mM}$ sucrose and $0.1 \mathrm{mM}$ EDTA. Mitochondria were prepared from heart homogenates using differential centrifugation after Nagarse digestion (Hara et al. 1980), and from the liver and kidney by the modified method of Packer (Yoon, 1982).

The lipid peroxide content of the mitochondria was measured by the thiobarbituric acid (TBA) method applied to the isolated mitochondria (Nagata et al. 1978). The reaction mixture contained $27.7 \mathrm{mM}$ sodium dodecyl sulfate, $13.9 \mathrm{mM}$ thiobarbituric acid, $33.5 \mathrm{mM}$ acetic acid and $6 \mathrm{mg}$ of mitochondrial protein in a final volume of $7 \mathrm{ml}$. The sample was heated in an oil bath at $95{ }^{\circ} \mathrm{C}$ for $45 \mathrm{~min}$, then cooled rapidly in ice water. $5 \mathrm{ml}$ of chloroform was added and 
the mixture was centrifuged at $2,500 \times \mathrm{g}$ for $10 \mathrm{~min}$. The supernatant was analyzed spectrophotometrically at $532 \mathrm{~nm}$. The lipid peroxide content in mitochondria was expressed as nanomoles of malondialdehyde (MDA) per mg protein of mitochondria.

The activity of glutathione peroxidase was measured according to the method of Paglia (Paglia et al. 1967). The reaction mixture contained $3 \mathrm{mg}$ of mitochondrial protein, $0.56 \mathrm{mM} \mathrm{NADPH}, 1.0$ unit glutathione reductase, $7.5 \mathrm{mM}$ sodium azide, $5 \mathrm{mM}$ GSH, $5 \mathrm{mM}$ EDTA and $0.05 \mathrm{M}$ phosphate buffer in a final volume of $3 \mathrm{ml}(\mathrm{pH}$ 7.0). The enzymatic reaction was initiated by the addition of $10.3 \mathrm{mM}$ hydrogen peroxide or $23 \mathrm{mM}$ tert-butyl hydroperoxide as a substrate. The reaction mixture was allowed to equilibrate at $22{ }^{\circ} \mathrm{C}$. The rate of GSSG formation was determined by observing the decrease in absorbance of the reaction mixture at $340 \mathrm{nM}$ as NADPH was converted to NADP. The activity of glutathione peroxidase was expressed as nanomoles of NADPH oxidized per min per mg protein of mitochondria.

Respiratory responses of isolated mitochondria were determined polarographically with a Clark oxygen electrode, as described previously (Ogura et al. 1979). The reaction medium contained $0.21 \mathrm{M}$ mannitol, $10 \mathrm{mM} \mathrm{KH}_{2} \mathrm{PO}_{4}, 10 \mathrm{mM} \mathrm{KCl}, 2 \mathrm{mM} \mathrm{NaCl}_{2}$, $0.2 \mathrm{mM}$ EDTA and $10 \mathrm{mM}$ Tris $-\mathrm{HCl}$ in a final volume of $3 \mathrm{ml}$ ( $\mathrm{pH} \mathrm{7.4)}$. It was allowed to equilibrate at $25{ }^{\circ} \mathrm{C}$. Each assay was carried out with $3 \mathrm{mg}$ of mitochondrial protein, $8.5 \mu \mathrm{M}$ rotenone and $2.7 \mathrm{mM}$ succinate, as a respiratory substrate. State 3 respiration was initiated by the addition of $0.21 \mathrm{mM}$ ADP. The oxygen consumption was expressed as nanomoles per min per mg protein. The state 3 , state 4 , respiratory control ratio ( $\mathrm{RCR}$ ) and $\mathrm{ADP} / \mathrm{O}$ ratio were calculated as described by Estabrook (1967). The protein concentration of the mitochondrial suspension was measured by the biuret method with bovine serum albumin (Sigma) as a standard (Colonick, 1967).

\section{Results}

\section{1) Lipid peroxide content in mitochondria}

Table 1 shows the lipid peroxide content of isolated mitochondria from the heart, liver and kidney of control and ADR-treated animals. The content of lipid peroxide in heart mitochondria was considerably larger in the ADR group than in the control group (about 1.5 folds, $\mathrm{p}<0.01$ ). On the other hand, the lipid peroxide content in liver mitochondria was only slightly larger in the ADR group (about 1.3 folds, $\mathrm{p}<$ $0.05)$, and the content in kidney mitochondria was not significantly different.

2) Glutathione peroxidase activity in mitochondria

Since the administration of ADR caused a greater elevation of lipid peroxidation in heart mitochondria than in mitochondria of the liver and kidney; glutathione peroxidase activity was determined. Glutathione peroxidase catalyzes the conversion of lipid peroxide to alcohol. Hydrogen peroxide and cumene hydroperoxide were used as substrates. Table 2 shows the glutathione peroxidase activities in mitochondria prepared from the heart, liver and kidney. The glutathione peroxidase activity was reduced the most by ADR in cardiac mitochondria.

\section{3) Respiratory responses of mitochondria}

Respiratory responses of mitochondria

TABLE 1

Lipid peroxide content in mitochondria isolated from control and adriamycintreated rats

\begin{tabular}{lcr}
\hline Organ & control group & ADR group \\
\hline heart & $0.91 \pm 0.11$ & $*_{1} .33 \pm 0.06$ \\
liver & $0.64 \pm 0.14$ & $* * 0.84 \pm 0.14$ \\
kidney & $1.06 \pm 0.16$ & $1.34 \pm 0.34$ \\
\hline
\end{tabular}

Lipid peroxide content was expressed as nanomoles per $\mathrm{mg}$ protein of mitochondria. $* \mathrm{p}<0.01 \quad * * \mathrm{p}<0.05$ 
TABLE 2

Glutathione peroxidase activity in mitochondria isolated from control and Adriamycin-treated rats

\begin{tabular}{lcccc} 
& \multicolumn{2}{c}{ control group } & \multicolumn{2}{c}{ ADR } \\
\cline { 2 - 5 } organ & $\begin{array}{c}\text { hydroup } \\
\text { peroxide }\end{array}$ & $\begin{array}{c}\text { tert-butyl } \\
\text { peroxide }\end{array}$ & $\begin{array}{c}\text { hydrogen } \\
\text { peroxide }\end{array}$ & $\begin{array}{c}\text { tert-butyl } \\
\text { peroxide }\end{array}$ \\
\hline heart & $428.7 \pm 68.9$ & $160.8 \pm 18.1$ & $* 242.2 \pm 21.6$ & $* 106.7 \pm 7.5$ \\
liver & $395.8 \pm 38.1$ & $263.3 \pm 25.8$ & $325.0 \pm 60.4$ & $210.0 \pm 27.4$ \\
kidney & $297.2 \pm 38.5$ & $261.7 \pm 46.6$ & $223.3 \pm 26.0$ & $190.0 \pm 42.1$ \\
\hline
\end{tabular}

Glutathione peroxidase activity was expressed as nanomoles NADPH oxidized per min per $\mathrm{mg}$ protein of mitochondria. $* \mathrm{p}<0.001$

TABLE 3

Oxygen consumption of mitochondria isolated from control and Adriamycin-treated rats

\begin{tabular}{lrrrc}
\hline & state 3 & state 4 & ADP/O & RCR \\
\hline $\begin{array}{l}\text { control group } \\
\quad \text { heart }\end{array}$ & $224 \pm 66$ & $44 \pm 12$ & $5.0 \pm 0.3$ & $1.6 \pm 0.1$ \\
$\quad$ liver & $98 \pm 12$ & $24 \pm 1$ & $4.1 \pm 0.3$ & $1.7 \pm 0.1$ \\
$\quad$ kidney & $241 \pm 67$ & $101 \pm 28$ & $2.4 \pm 0.3$ & $1.5 \pm 0.1$ \\
$\begin{array}{l}\text { Adriamycin- } \\
\text { treated group }\end{array}$ & & & & \\
$\quad$ heart & $205 \pm 24$ & $68 \pm 16$ & $* 4.0 \pm 0.5$ & $* 1.3 \pm 0.1$ \\
$\quad$ liver & $84 \pm 21$ & $20 \pm 5$ & $4.2 \pm 0.5$ & $1.8 \pm 0.3$ \\
$\quad$ kidney & $245 \pm 47$ & $101 \pm 47$ & $2.4 \pm 0.3$ & $1.5 \pm 0.3$ \\
\hline
\end{tabular}

Oxygen consumption of mitochondria was expressed as nano atoms of oxygen per mg protein of mitochondria.

$* \mathrm{p}<0.001$

were determined with succinate as a substrate. Respiratory control ratio (RCR) values and $\mathrm{ADP} / \mathrm{O}$ ratios for each group are also shown in Table 3. Heart mitochondria from the control group had an RCR value and $\mathrm{ADP} / \mathrm{O}$ ratio of $5.0 \pm 0.3$ and 1. $6 \pm 0.1$, respectively. The $R C R$ values and $\mathrm{ADP} / \mathrm{O}$ ratios of the $\mathrm{ADR}$-group were smaller than the values from the control group. The respiratory function of mitochondria from the liver and kidney were not affected significantly by the administration of ADR. These results confirm that ADR selectively causes mitochondrial dysfunction in the heart.

\section{Discussion}

There are many reports discussing car dioselective toxicity (Arcamone, 1981), however the pathogenesis of ADR-induced cardiotoxicity is not completely established, Mitochondria are the main site of energy productions in the cell. The results of this study indicate that cardiac muscle mitochondria are quite sensitive to ADR. ADR induced a larger increase of lipid peroxide in the heart than in the liver and kidney. These results suggest that a biochemical disturbance of the heart mitochondrial inner membrane occurred with the functional 
disturbance induced by ADR.

Glutathione peroxidase is capable of detoxifying the lipid peroxide through the glutathione reductase system. Doroshow et al. (1980) reported that the mouse heart has 150 times less catalase activity and nearly four times less superoxide dismutase activity than the liver. This strongly suggests that glutathione peroxidase is a major endogenous cellular defense mechanism against lipid peroxide in the heart. To determine the involvement of glutathione peroxidase in the detoxification of ADRinduced lipid peroxidation, the activities of glutathione peroxidase of mitochondria from the heart, liver and kidney were determined. ADR resulted in a decrease of glutathione peroxidase activity in the heart, however the activities in the liver and kidney were not affected. These results confirm that ADR-induced lipid peroxidation is partially due to a disturbance of the enzymatic detoxification of lipid peroxide.

The enzymes for electron transport and oxidative phosphorylation are located at the inner membrane of mitochondria. It can be assumed that lipid peroxidation in the inner membrane will occur simultaneously with a decrease in respiratory function. The effects of ADR on the respiratory responses of mitochondria were examined using polarography. The administration of ADR resulted in respiratory damage to cardiac mitochondria.

In a separate paper (Yoon, 1982) using an anisotropic inhibitor of ethidium bromide (Higuti, 1978), it was demonstrated that the disturbance of negative charge formation at the inner membrane of mitochondria was greater in heart mitochondria, than in mitochondria of the liver and kidney. The results of the present paper, indicate that heart mitochondria are quite susceptible to ADR. The biochemical pathogenesis of ADR-induced cardiotoxicity will be further elucidated in subsequent papers.

\section{References}

Arcamone, F. (1981). Studies related to toxic side-effects. In Doxoburicin: Anticancer Antibiotics: Medical Chemistry: A Series of Monographs, vol. 17, pp.153-157, New York : Academic Press.

Colonick, S.P. and Kaplan, N. O. (1967). Biuret method. Method in Enzymology, 10, pp. 574580, New York: Academic Press.

Doroshow, J. H., Locker, G. Y. and Myers, C.E. (1980). Enzymatic defenses of the mouse heart against reactive oxygen metabolites. J. Clin. Invest. 65, 128-135.

Est ABRooK, R. (1967). Mitochondrial respiratory control and the polarographic measurement of ADP:O ratios. Method in Enzymology, 10,41-47.

Hara, H., Katsuki, T., Ono, T. and Ogura, R. (1980). Improved method for preparation of mitochondria from rat heart by using ultraturrax and Proteinase. J. Kurume Med. Ass. 43, 333-340.

Higuti, T., Yokota, M., Arakaki, N., Hattori, A. and TANI, I. (1978). Sideness of inhibition of energy transduction in oxidative phosphorylation in rat liver mitochondria by ethidium bromide. Biochem. Biophys. Acta, 503, 211-222.

Myers, C. E., Mcguire, W.P., Liss, R. H., Ifrim, I., Grontzinger, K. and Young, R. C. (1977). Adriamycin: The role of lipid peroxidation in cardiac toxicity and tumor response. Science, 197, $165-167$.

Nagata, O., Sayanagi, H. and Ogura, R. (1978). Improved method for the determination of lipid peroxide in the isolated mitochondria of rat liver. J. Kurume Med. Ass. 41, 292-298.

Ogura, R., Toyama, H., Shimada, T. and MuraKAMI, M. (1979). The role of Ubiquinone (Coenzyme Q-10) in preventing adriamycininduced mitochondrial disorders in rat heart. J. Applied Biochem. 1, 325-335.

Ogura, R. (1982). Biochemical aspect of adriamycin-induced cardiotoxicity and usefulness of antioxidant in preventing adriamycin-induced mitochondrial disorders. J. Kurume Med. Ass. 45, 137-156.

Paglia, D. E. and Vlentine, W. N. (1967). Studies on the quantitative and qualitative characterization of erythocyte glutathione peroxidase. J. Lab. and Clin. Med. 70, 158-169.

Yoon, S. B. (1982). Organ Specificity of adriamycin-induced mitochondrial disturbance. J. Kurume Med. Ass. 45, 993-1008. 